\title{
THE COMPARISON BETWEEN WEEKLY BLEOMYCIN WITH THREE-WEEKLY CISPLATIN AND 5-FU DELIVERED CONCURRENTLY WITH RADIOTHERAPY IN HEAD AND NECK CANCER
}

\author{
R. Balasankar ${ }^{1}$, B. Nehru², Syed Fayaz Ahmed ${ }^{3}$
}

${ }^{1}$ Assistant Professor, Department of Radiation Oncology, MNJ Institute of Oncology \& Regional Cancer Centre, Hyderabad. ${ }^{2}$ Assistant Professor, Department of Radiation Oncology, MNJ Institute of Oncology \& Regional Cancer Centre, Hyderabad. ${ }^{3}$ Assistant Professor, Department of Radiation Oncology, Nizam Institute of Medical Science, Hyderabad.

\begin{abstract}
BACKGROUND

Head and neck cancer is most common in South-East Asia. In India, it is a leading cause of cancer related mortality and morbidity. Affected males were more than females, it is mainly to the consumption of the tobacco. Surgery and radiotherapy with or without chemotherapy are the most frequently used therapeutic modalities. Concurrent chemoradiation improves overall survival, disease free survival and locoregional control and has become the standard treatment for squamous cell carcinoma of head and neck.

The main objective of the study is to determine the response, acute toxicity and compliance of treatment with concurrent chemoradiation using cisplatin and 5-FU versus bleomycin in squamous cell carcinoma of head and neck.
\end{abstract}

\section{MATERIALS AND METHODS}

The present study was done in the Department of Radiotherapy, MNJ Institute of Oncology and RCC. The patients were randomly selected from 2013 to 2015 and were allotted to ARM-A - cisplatin and 5-FU; and ARM-B - bleomycin. ARM-A were treated with cisplatin $100 \mathrm{mg} / \mathrm{m}^{2}$ in divided dose IV infusion, 5-FU $750 \mathrm{mg} / \mathrm{m}^{2} \mathrm{IV}$ infusion for 3 days once in every 3 weeks for $3 \mathrm{cycles}$; and ARM-B were treated with bleomycin $15 \mathrm{mg}$ IV push once per week for 6 weeks, both ARMs received radiotherapy concurrently.

\section{RESULTS}

Arm-A: Complete response 22 patients (61\%), partial response $12(33 \%)$, no response 2 (6\%). Arm-B: Complete response 21 (60\%), partial response $13(37 \%)$, no response 1 (3\%) respectively. When compared to Arm-A mode of administration of bleomycin is easy and convenient to the patients as hydration is not required. Tumours confined to oral cavity have shown good response though mucosal toxicity is more.

\section{CONCLUSION}

Concurrent weekly bleomycin is recommended in squamous cell carcinoma of oral cavity to achieve meaningful regression and probably survival benefit.

\section{KEYWORDS}

Acute Toxicity, Compliance, Concurrent Chemoradiotherapy, Head and Neck Cancer, Mucositis, Squamous Cell Carcinoma.

HOW TO CITE THIS ARTICLE: Balasankar R, Nehru B, Ahmed SF. The comparison between weekly bleomycin with three-weekly cisplatin and 5-FU delivered concurrently with radiotherapy in head and neck cancer. J. Evolution Med. Dent. Sci. 2017;6(22): 1772-1777, DOI: $10.14260 / \mathrm{Jemds} / 2017 / 390$

\section{BACKGROUND}

The head and neck cancers form the $7^{\text {th }}$ most common cancer worldwide. Its frequency is high in South East Asian countries and is linked mainly to the chewing and smoking tobacco and alcohol intake. In India head and neck cancers are leading causes of cancer morbidity and mortality affecting both males (25\%-30\%) and females (15\%).\{1\}

Surgery and radiotherapy (RT) with or without chemotherapy (CT) are the most frequently used therapeutic modalities in head and neck cancers. In early stage (I-II), surgery or radiotherapy has shown good comparable results. For advance stage (III-IV) with large primary tumours, the primary curative modalities are surgery, radiotherapy

Financial or Other, Competing Interest: None.

Submission 27-12-2016, Peer Review 21-02-2017,

Acceptance 27-02-2017, Published 16-03-2017.

Corresponding Author:

Dr. R. Balasankar.

MNJ Institute of Oncology \& Regional Cancer Centre, Red Hills,

Lakdikapool,

Hyderabad-500004,

Telangana.

E-mail: sankarrmc2004@gmail.com

DOI: $10.14260 /$ jemds $/ 2017 / 390$

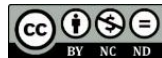

and chemotherapy. Most of the time chemotherapy is used in neoadjuvant setting.

The principle objective of combining radiotherapy and chemotherapy (CCRT) is to increase local tumour control, decrease the distant metastasis and improve the survival. To improve upon response rates and survival in head and neck cancer, various researchers have advocated various regimens with different drugs. Drugs most commonly used in concurrent chemotherapy include cisplatin, carboplatin, 5fluorouracil, paclitaxel, hydroxyurea and bleomycin.

For squamous cell carcinoma of head and neck (SCCHN), $100 \mathrm{mg} / \mathrm{m}^{2}$ dose of cisplatin administered once every 3 weeks concurrently with radiotherapy is the commonly recommended treatment regimen. Its high emetic potential, neurotoxicity, and ototoxicity demand further efforts to be made towards improving its therapeutic and toxicity profiles. $40 \mathrm{mg} / \mathrm{m}^{2}$ dose of cisplatin administered once per week has been widely used in concurrent CRT for cervical cancer as it is effective and has a relatively low toxicity. $\{2,3,4,5\}$ A randomised phase III trial that evaluated the weekly administration of $40 \mathrm{mg} / \mathrm{m}^{2}$ cisplatin plus RT versus RT alone for the treatment of Nasopharyngeal cancer also demonstrated favourable outcomes in patients with an advanced T-stage treated by CCRT. $\{6,7\}$ 
Several studies have compared the weekly and 3-weekly cisplatin CCRT regimens in patients with SCCHN and the results have been inconclusive. $\{8,9,10\}$ However, no randomised controlled trials have compared the efficacy and toxicity profiles of bleomycin versus cisplatin and 5-FU concurrently with radiotherapy in SCCHN.

Concurrent chemoradiotherapy (CCRT) improves overall survival (OS), disease-free survival (DFS) and local regional control and has become the standard treatment for squamous cell carcinoma in head and neck (SCCHN). $\{11,12,13\}$ The main objective of this study is to determine the response, acute toxicity and the compliance of treatment with concurrent chemoradiation using cisplatin and 5-FU versus bleomycin in head and neck cancer.

\section{MATERIALS AND METHODS}

Present study was done in the Department of Radiotherapy in MNJ Institute of Oncology and Regional Cancer Centre. The patients were randomly selected from year 2013 to 2015 and were allotted two arms. ARM-A - 36 patients (cisplatin + 5-FU + RT), ARM-B - 35 patients (bleomycin + RT), based on inclusion and exclusion criteria.

Prior to the onset of therapy, the patients were thoroughly informed about all aspects of the study and regulatory requirement that needs to be met for informed consent.

\section{Patients were selected according to the following} Inclusion Criteria:

- Patients of both sexes between 18 - 70 years

- T1-T2 with positive neck nodes and T3-T4 cases

- Histologically proven squamous cell carcinoma of head and neck (SCCHN)

- No prior radiotherapy or chemotherapy

- Eastern Cooperative Oncology Group (ECOG) performance status (PS) of

- $0-2$

- Complete blood count, HB at least $10 \mathrm{~g} \%$

- WBC more than 3000 cells/dL.

- Platelets $>100000$ cells $/ \mathrm{dL}$.

- Routine Blood biochemistry panel - Renal and Liver functions

- Radiological

- Chest -X-ray PA view.

- OPG of the mandible.

- CT scans of head and neck when required.

- Ultrasonogram of the abdomen.

\section{Exclusion Criteria}

- Poor performance status (PS) $>2$.

- Systemic diseases (comorbidity conditionsHTN/DM/COPD/Renal/Liver).

- Oral submucosal fibrosis.

- Pregnancy.

- Evidence of distant metastasis.

\section{Methods}

All study participants underwent an extensive pre-treatment evaluation, which included-

- Complete history, clinical examination and staging of the disease.

- Complete dental examination and extraction of the decayed and loose teeth under antibiotic coverage. The patients who were randomised ARM-A were treated with cisplatin $100 \mathrm{mg} / \mathrm{m}^{2}$ in divided dose IV infusion for 2 days and 5 -FU $750 \mathrm{mg} / \mathrm{m}^{2}$ IV infusion for 3 days once in every 3 weeks for 3 cycles concurrently with radiotherapy.

The patients who were randomised ARM-B were treated with bleomycin $15 \mathrm{mg}$ IV push once per week for 6 weeks concurrently with radiotherapy. Radiotherapy was administered using $6 \mathrm{MV}$ photon beam with a conventional fractionation. Dose of $2 \mathrm{~Gy} /$ fraction/day and 5 days per week. Phase-I - $44 \mathrm{~Gy} / 22 \# 5 \#$ per week -for primary tumour and lymph-node drainage areas, Phase-II - 22 Gy/11\# 5\# per week- boost dose sparing the spinal cord all patients were irradiated with a total dose of $66 \mathrm{~Gy} / 33$ \# over 6.5 weeks.

\section{Data Collection and Statistical Analysis}

The collected data was analysed using standard statistical software package (SSSP version 20.0). The response, acute toxicity and compliance of treatment were analysed in both ARMs. Both ARMs were compared using chi-square test to check whether they were balanced in terms of patients and disease-related characteristics like age, sex, performance status and tumour site, stage, histology.

\section{RESULTS}

Fifty patients were taken into the study; they were divided in to two arms (ARM-A - 36 and ARM-B - 35). Maximum incidence of age is $3^{\text {rd }}$ to $6^{\text {th }}$ decade, male to female ratio $7: 3$ in both ARMs. Host and tumour characteristics is shown in Table-1. Response relation to Primary site of the tumour, stage, and histological grade in both ARMs are shown in Table-2; and overall toxicity, acute non-haematological and haematological toxicity are shown in Table- 3 .

The intensity of reaction is increased at the end of the 3 rd, $4^{\text {th }}$ and $5^{\text {th }}$ week, mucosal toxicity varied from grade II to grade III. The intensity was so severe that radiation therapy was interrupted and the patients were managed with best supportive care. Arm-A: Complete response 22 patients (61\%), partial response 12 (33\%), no response 2 (6\%). ArmB: Complete response $21(60 \%)$, partial response $13(37 \%)$, no response $1(3 \%)$ respectively.

\begin{tabular}{|c|c|c|}
\hline $\begin{array}{c}\text { Characteristics } \\
\text { of Host } \\
\text { and Tumour }\end{array}$ & $\begin{array}{c}\text { ARM-A } \\
\text { (Cisplatin-100 mg/m² } \\
\text { and 5-FU-750 mg/m²) } \\
\text { 3-weekly } \\
\text { Number }=36\end{array}$ & $\begin{array}{c}\text { ARM-B } \\
\text { (Bleomycin-15 } \\
\text { mg) weekly } \\
\text { Number }=35\end{array}$ \\
\hline $\begin{array}{c}\text { Gender } \\
\text { Male } \\
\text { Female }\end{array}$ & $\begin{array}{l}26(72 \%) \\
10(28 \%)\end{array}$ & $\begin{array}{l}25(71 \%) \\
10(19 \%)\end{array}$ \\
\hline $\begin{array}{l}\text { Age (years) } \\
\text { mean age }\end{array}$ & $\begin{array}{c}28-60 \\
44\end{array}$ & $\begin{array}{c}30-60 \\
45\end{array}$ \\
\hline $\begin{array}{c}\text { Primary Site } \\
\text { Oral cavity } \\
\text { Oropharynx } \\
\text { Hypopharynx } \\
\text { Supraglottis }\end{array}$ & $\begin{array}{c}18(50 \%) \\
9(25 \%) \\
6(17 \%) \\
3(8 \%)\end{array}$ & $\begin{array}{l}17(49 \%) \\
7(20 \%) \\
7(20 \%) \\
4(11 \%)\end{array}$ \\
\hline $\begin{array}{l}\text { Stage } \\
\text { Stage-II } \\
\text { Stage-III } \\
\text { Stage-IV }\end{array}$ & $\begin{array}{c}4(11 \%) \\
18(50 \%) \\
14(39 \%)\end{array}$ & $\begin{array}{c}3(9 \%) \\
15(44 \%) \\
17(47 \%)\end{array}$ \\
\hline $\begin{array}{c}\text { Tumour Size } \\
\text { T2 } \\
\text { T3 } \\
\text { T4 }\end{array}$ & $\begin{array}{c}4(11 \%) \\
20(56 \%) \\
12(33 \%)\end{array}$ & $\begin{array}{c}4(11 \%) \\
21(60 \%) \\
10(29 \%)\end{array}$ \\
\hline $\begin{array}{c}\text { Nodal Status } \\
\text { N1 } \\
\text { N2 } \\
\text { N3 }\end{array}$ & $\begin{array}{c}3(8 \%) \\
23(64 \%) \\
10(28 \%)\end{array}$ & $\begin{array}{c}2(6 \%) \\
23(66 \%) \\
10(28 \%)\end{array}$ \\
\hline Table & st and Tumour Charac & istics \\
\hline
\end{tabular}




\begin{tabular}{|c|c|c|c|c|c|c|}
\hline \multirow{2}{*}{$\begin{array}{c}\text { Characteristics } \\
\text { Tumour size } \\
\text { T2 }\end{array}$} & \multicolumn{3}{|c|}{$\begin{array}{c}\text { ARM-A } \\
\text { N=36 } \\
\text { CR PR NR }\end{array}$} & \multicolumn{3}{|c|}{$\begin{array}{c}\text { ARM-B } \\
\text { N=35 } \\
\text { CR PR NR }\end{array}$} \\
\hline & $\begin{array}{c}4(11 \%) \\
15(42 \%) \\
3(8 \%)\end{array}$ & $\begin{array}{c}- \\
5(14 \%) \\
7(19 \%)\end{array}$ & $\begin{array}{c}- \\
- \\
2(6 \%) \\
\end{array}$ & $\begin{array}{c}4(11 \%) \\
15(43 \%) \\
2(6 \%)\end{array}$ & $\begin{array}{c}- \\
8(23 \%) \\
5(14 \%)\end{array}$ & $\begin{array}{c}- \\
- \\
1(3 \%)\end{array}$ \\
\hline $\begin{array}{c}\text { Nodal status } \\
\text { N1 } \\
\text { N2 } \\
\text { N3 }\end{array}$ & $\begin{array}{c}2(6 \%) \\
17(47 \%) \\
3(8 \%) \\
\end{array}$ & $\begin{array}{c}- \\
8(22 \%) \\
4(11 \%)\end{array}$ & $\begin{array}{c}- \\
- \\
2(6 \%) \\
\end{array}$ & $\begin{array}{c}1(3 \%) \\
16(46 \%) \\
4(11 \%)\end{array}$ & $\begin{array}{c}- \\
9(26 \%) \\
4(11 \%)\end{array}$ & $\begin{array}{c}- \\
- \\
1(3 \%) \\
\end{array}$ \\
\hline $\begin{array}{l}\text { Grade } \\
\text { Well } \\
\text { Moderate } \\
\text { Poor }\end{array}$ & $\begin{array}{c}4(11 \%) \\
14(39 \%) \\
4(11 \%)\end{array}$ & $\begin{array}{c}1(3 \%) \\
9(25 \%) \\
2(5 \%)\end{array}$ & $\begin{array}{c}- \\
1(3 \%) \\
1(3 \%) \\
\end{array}$ & $\begin{array}{c}5(14 \%) \\
14(40 \%) \\
2(6 \%) \\
\end{array}$ & $\begin{array}{c}1(3 \%) \\
8(23 \%) \\
4(11 \%)\end{array}$ & $\begin{array}{c}- \\
- \\
1(3 \%) \\
\end{array}$ \\
\hline $\begin{array}{l}\text { Primary site } \\
\text { Oral Cavity } \\
\text { Oropharynx } \\
\text { Hypopharynx } \\
\text { Supraglottis }\end{array}$ & $\begin{array}{c}13(36 \%) \\
4(11 \%) \\
7(19 \%) \\
3(8 \%)\end{array}$ & $\begin{array}{c}4(11 \%) \\
2(6 \%) \\
1(3 \%) \\
-\end{array}$ & $\begin{array}{c}1(3 \%) \\
1(3 \%) \\
- \\
-\end{array}$ & $\begin{array}{c}17(48 \%) \\
4(11 \%) \\
6(17 \%) \\
3(9 \%)\end{array}$ & $\begin{array}{c}- \\
3(9 \%) \\
- \\
1(3 \%)\end{array}$ & $\begin{array}{c}- \\
- \\
1(3 \%) \\
-\end{array}$ \\
\hline
\end{tabular}

Note; $\mathrm{N}=$ Number, $\mathrm{CR}=$ Complete Response, $\mathrm{PR}=$ Partial Response, NR=No Response

\begin{tabular}{|c|c|c|}
\hline CCRT- Toxicity & $\begin{array}{c}\text { ARM-A } \\
\text { Cisplatin + 5-FU } \\
\mathrm{N}=36\end{array}$ & $\begin{array}{c}\text { ARM-B } \\
\text { Bleomycin } \\
\mathrm{N}=35\end{array}$ \\
\hline $\begin{array}{l}\text { Overall toxicity } \\
\text { Grade-2 } \\
\text { Grade-3 } \\
\text { Grade-4 }\end{array}$ & $\begin{array}{c}8(22 \%) \\
26(72 \%) \\
2(6 \%)\end{array}$ & $\begin{array}{c}4(11 \%) \\
28(80 \%) \\
3(9 \%)\end{array}$ \\
\hline $\begin{array}{c}\text { Non-haematological toxicity } \\
\text { Mucositis } \\
\text { < Grade-3 } \\
>\text { Grade-3 } \\
\text { Pharyngitis } \\
<\text { Grade-3 } \\
>\text { Grade-3 } \\
\text { Stomatitis } \\
<\text { Grade-3 } \\
>\text { Grade-3 } \\
\text { Laryngeal oedema } \\
<\text { Grade-3 } \\
>\text { Grade-3 } \\
\text { Dermatitis } \\
<\text { Grade-3 } \\
>\text { Grade-3 } \\
\text { Nausea/vomiting } \\
<\text { Grade-3 } \\
>\text { Grade-3 }\end{array}$ & $\begin{array}{c}21(58 \%) \\
15(42 \%) \\
21(58 \%) \\
15(42 \%) \\
\\
17(47 \%) \\
19(53 \%) \\
6(17 \%) \\
30(83 \%) \\
22(89 \%) \\
4(11 \%) \\
4(11 \%) \\
22(89 \%)\end{array}$ & $\begin{array}{c}10(29 \%) \\
25(71 \%) \\
17(49 \%) \\
18(51 \%) \\
\\
18(51 \%) \\
17(49 \%) \\
27(77 \%) \\
8(23 \%) \\
14(40 \%) \\
21(60 \%) \\
30(86 \%) \\
5(14 \%)\end{array}$ \\
\hline $\begin{array}{c}\text { Haematological toxicity } \\
\text { Anaemia } \\
\text { < Grade-3 } \\
>\text { Grade-3 } \\
\text { Leukopenia } \\
\text { <Grade-3 } \\
\text { > Grade-3 } \\
\text { Neutropenia } \\
<\text { Grade-3 } \\
>\text { Grade-3 } \\
\text { Thrombocytopenia } \\
\text { < Grade-3 } \\
>\text { Grade-3 }\end{array}$ & $\begin{array}{c}23(64 \%) \\
13(36 \%) \\
4(11 \%) \\
22(89 \%) \\
23(64 \%) \\
13(36 \%) \\
22(89 \%) \\
4(11 \%)\end{array}$ & $\begin{array}{c}30(86 \%) \\
5(14 \%) \\
\\
30(86 \%) \\
5(14 \%) \\
35(100 \%) \\
0 \\
\\
35(100 \%) \\
0\end{array}$ \\
\hline
\end{tabular}




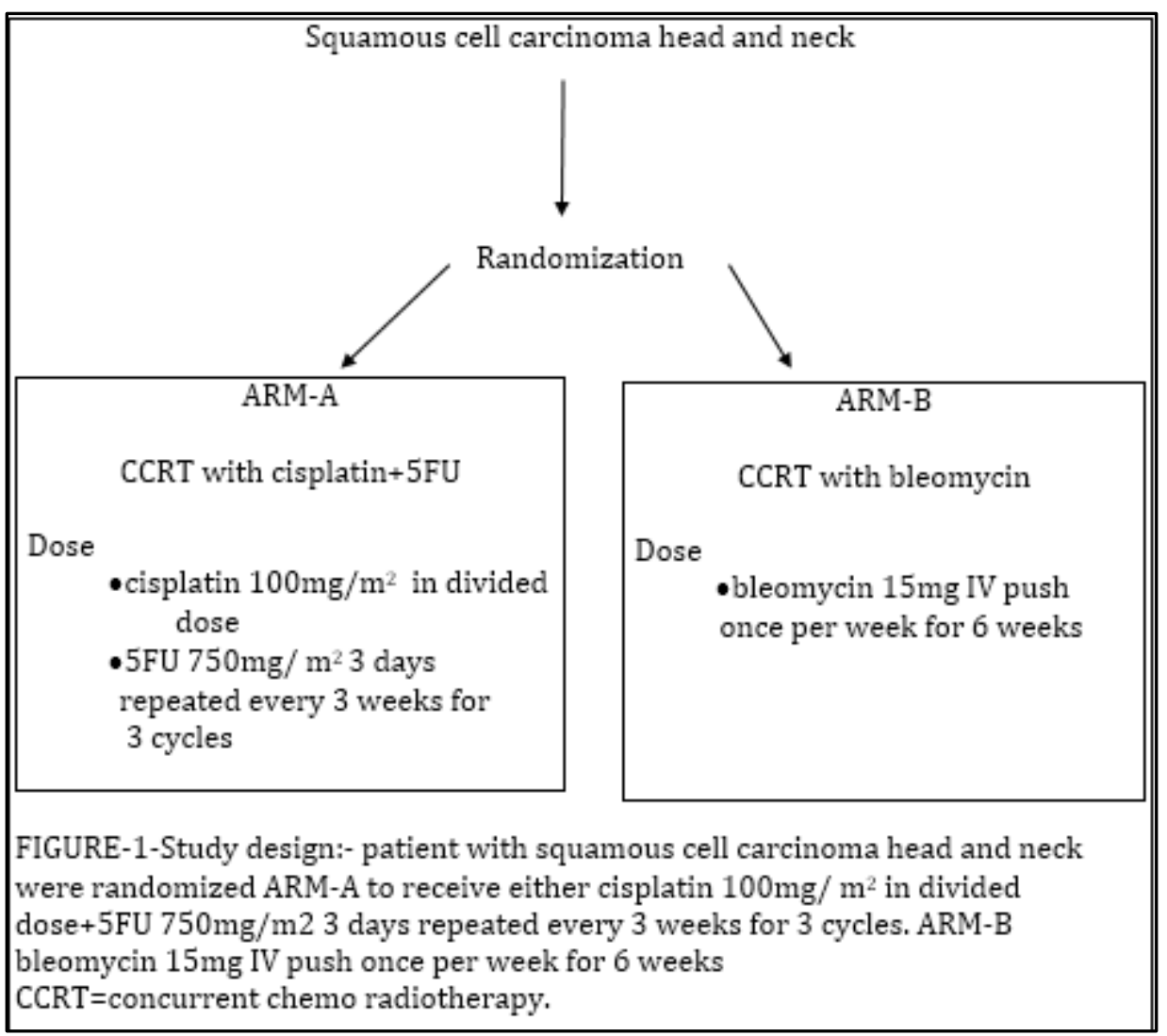

Figure 1. Study Design

\section{DISCUSSION}

Radiotherapy with or without chemotherapy is the most frequently used therapeutic modality in head and neck cancer.

Concurrent chemoradiotherapy (CCRT) improves overall survival (OS), disease-free survival (DFS) and locoregional control and has become the standard treatment for squamous cell carcinoma of head and neck. $\{6,9,10,11,12,13\}$

Several single- and multi-institutional trials have reported both survival and locoregional control benefits from more aggressive concurrent radiation and multi-agent chemotherapy regimens. $\{14-17\}$ Concurrent administration of $100 \mathrm{mg} / \mathrm{m}^{2}$ cisplatin once every three weeks and RT is recommended as the standard regimen of adjuvant CCRT for SCCHN because two large scale randomised trials used this regimen..$^{18,19\}}$ Majority of the studies used cisplatin 100 $\mathrm{mg} / \mathrm{m}^{2}$ and 5 -FU $750 \mathrm{mg} / \mathrm{m}^{2}$ D1-D4 every 3 weeks for 3 courses during radiation. This gain was due to increased locoregional control rate; however, concurrent chemoradiotherapy was associated with statistically significant increases in acute toxicity especially severe mucositis, sometimes unacceptable systemic toxicity, particularly haematological toxicity such as febrile neutropenia and sepsis. $\{20,21\}$

Northern California Oncology Group (NCOG) and European Organization for the Research and Treatment of Cancer (EORTC) tested concurrent RT with single agent chemotherapy bleomycin versus radiotherapy alone.\{22,23\} Fractionation was similar in the two studies, but patients in the EORTC trial received $15 \mathrm{mg}$ of bleomycin twice weekly during the first 5 weeks of RT for a total dose of $150 \mathrm{mg}$ whereas the NCOG patients received bleomycin $5 \mathrm{mg}$ twice weekly for a total dose of $70 \mathrm{mg}$. Acute mucosal and skin toxicity was worse in the RT/bleomycin ARM in both trials, but the outcomes were quite different in both trials. Toxicity significantly prolonged the RT delivery time in $30 \%$ of the combined modalities in patients in the EORTC trial, but not in any of the RT alone patients. This prolongation of treatment time in such a large proportion of patient may have negated any benefit accrued from the use of concurrent therapy. There were no differences in overall treatment time between the two treatment ARMs in the NCOG trials.

The EORTC trial showed no improvement in DFS or OS but in NCOG RT/bleomycin ARM led to a statistically significant doubling of the locoregional control and DFS, as well as a near significant improvement in OS from $24 \%$ to $43 \%$, because lower doses may improve the therapeutic ratio more effectively than higher dose.

In our studies, we have given bleomycin $15 \mathrm{mg}$ weekly to a total dose of $90 \mathrm{mg}$. When compared to ARM-A (cisplatin +5 -FU +RT) mode of administration of bleomycin is easy and convenient for patients as hydration is not required. Tumours confined to oral cavity have shown good response to ARM$\mathrm{B}$ (bleomycin + RT) though mucosal toxicity is more; in contrary tumours confined to Oropharynx, hypopharynx and supraglottis have shown good response to ARM-A. The intensity of reactions increased at the end of $3^{\text {rd }}, 4^{\text {th }}, 5^{\text {th }}$, week, mucosal toxicity varied from grade II to grade III, patients were able to continue radiotherapy without interruption with supportive therapy.

Chemotherapy timing should be tailored in such a way that the drug acts as a radiosensitiser. However, as the 
chemoradiation increased mucosal toxicity compared to radiotherapy alone, it may cause treatment interruption leading to increased duration of treatment of more than 6 to 7 weeks. This gap may cause tumour repopulation leading to development of resistant strains.

Hence, concurrent chemoradiation should be planned very carefully and radiotherapy technique should be perfect.

\section{CONCLUSION}

Our study is comparable to all other positive randomised trials with concurrent chemoradiation in squamous cell carcinoma of head and neck. The CCRT regimen is tolerable with appropriate supportive care. Locoregional and distant metastasis control are likely. We do not have overall survival in our study as the study period is short. Hence, concurrent weekly bleomycin is recommended in squamous cell carcinoma of oral cavity (OSCC) to achieve meaningful regression and probably survival benefit.

\section{REFERENCES}

[1] Sanghvi LD, Rao DN, Joshi S. Epidemiology of head and neck cancer. Semin Surg Oncol 1989;5(5):305-9.

[2] Keys HM, Bundy BN, Stehman FB, et al. Cisplatin, radiation, and adjuvant hysterectomy compared with radiation and adjuvant hysterectomy for bulky stage IB cervical carcinoma. N Engl J Med 1999;340(15):1154-61.

[3] Lanciano R, Calkins A, Bundy BN, et al. Randomized comparison of weekly cisplatin or protracted venous infusion of fluorouracil in combination with pelvic radiation in advanced cervix cancer: a gynecologic oncology group study. J Clin Oncol 2005;23(33):828995.

[4] Pearcey R, Brundage M, Drouin P, et al. Phase III trial comparing radical radiotherapy with and without cisplatin chemotherapy in patients with advanced squamous cell cancer of the cervix. J Clin Oncol 2002;20(4):966-72.

[5] Rose PG, Bundy BN, Watkins EB, et al. Concurrent cisplatin-based radiotherapy and chemotherapy for locally advanced cervical cancer. $N$ Engl J Med 1999;340(15):1144-53.

[6] Chan AT, Leung SF, Ngan RK, et al. Overall survival after concurrent cisplatin-radiotherapy compared with radiotherapy alone in locoregionally advanced nasopharyngeal carcinoma. J Natl Cancer Inst 2005;97(7):536-9.

[7] Chan AT, Teo PM, Ngan RK, et al. Concurrent chemotherapy-radiotherapy compared with radiotherapy alone in locoregionally advanced nasopharyngeal carcinoma: progression-free survival analysis of a phase III randomized trial. J Clin Oncol 2002;20(8):2038-44.

[8] Geeta SN, Padmanabhan TK, Samuel J, et al. Comparison of acute toxicities of two chemotherapy schedules for head and neck cancers. J Cancer Res Ther 2006;2(3):100-4.

[9] Ho KF, Swindell R, Brammer CV. Dose intensity comparison between weekly and 3-weekly cisplatin delivered concurrently with radical radiotherapy for head and neck cancer: a retrospective comparison from New Cross hospital, Wolverhampton, UK. Acta Oncol 2008;47(8):1513-8.

[10] Uygun K, Bilici A, Karagol H, et al. The comparison of weekly and three-weekly cisplatin chemotherapy concurrent with radiotherapy in patients with previously untreated inoperable non-metastatic squamous cell carcinoma of the head and neck. Cancer Chemother Pharmacol 2009;64(3):601-5.

[11] Gupta T, Agarwal JP, Ghosh-Laskar S, et al. Radical radiotherapy with concurrent weekly cisplatin in loco-regionally advanced squamous cell carcinoma of the head and neck: a single-institution experience. Head Neck Oncol 2009;1:17.

[12] Marcu L, van Doorn T, Olver I. Cisplatin and radiotherapy in the treatment of locally advanced head and neck cancer-a review of their cooperation. Acta Oncol 2003;42(4):315-25.

[13] Ang KK. Concurrent radiation chemotherapy for locally advanced head and neck carcinoma: are we addressing burning subjects? J Clin Oncol 2004;22(23):4657-9.

[14] Adelstein DJ, Saxton JP, Lavertu P, et al. A phase III randomized trial comparing concurrent chemotherapy and radiotherapy with radiotherapy alone in resectable stage III and IV squamous cell head and neck cancer: preliminary results. Head Neck 1997;19(7):567-75.

[15] Wendt TG, Grabenbauer GG, Rodel CM, et al. Simultaneous radiochemotherapy versus radiotherapy alone in advanced head and neck cancer: a randomized multicentre study. J Clin Oncol 1998;16(4):1318-24.

[16] Brizel DM, Albers ME, Fisher SR, et al. Hyperfractionated irradiation with or without concurrent chemotherapy for locally advanced head and neck cancer. N Engl J Med 1998;338(25):1798804.

[17] Calais G, Alfonsi M, Bardet E, et al. Randomized trial of radiation therapy versus concomitant chemotherapy and radiation therapy for advanced-stage oropharynx carcinoma. J Natl Cancer Inst 1999;91(24):2081-6.

[18] Bernier J, Domenge C, Ozsahin M, et al. Postoperative irradiation with or without concomitant chemotherapy for locally advanced head and neck cancer. N Engl J Med 2004;350(19):1945-52.

[19] Cooper JS, Pajak TF, Forastiere AA, et al. Postoperative concurrent radiotherapy and chemotherapy for highrisk squamous-cell carcinoma of the head and neck. N Engl J Med 2004;350(19):1937-44.

[20] Urba SG, Forastiere AA, Wolf GT, et al. Intensive induction chemotherapy and radiation for organ preservation in patients with advanced resectable head and neck carcinoma. J Clin Oncol 1994;12(5):946-53.

[21] El-Sayed S, Nelson N. Adjuvant and adjunctive chemotherapy in the management of squamous cell carcinoma of the head and neck region. A metaanalysis of prospective and randomized trials. J Clin Oncol 1996;14(3):838-47. 
[22] Eschwege F, Sancho-Garnier H, Gerard JP, et al. Tenyear results of randomized trial comparing radiotherapy and concomitant bleomycin to radiotherapy alone in epidermoid carcinomas of the oropharynx: experience of the European organization for research and treatment of cancer. NCI Monogr 1988;(6):275-8.
[23] Fu KK, Phillips TL, Silverberg IJ, et al. Combined radiotherapy and chemotherapy with bleomycin and methotrexate for advanced inoperable head and neck cancer: update of a northern California oncology group randomized trial. J Clin Oncol 1987;5(9):14108. 